\title{
Assessment of Innovative Development of the Russian Economy and Mathematical Modelling
}

\author{
Victor Orlov ${ }^{1}{ }^{*}$ Tatiana Ivanova ${ }^{2}$, Galina Sokolova ${ }^{2}$, Valentina Arkhipova ${ }^{2}$, \\ Anna Ivanova ${ }^{2}$
}

\author{
${ }^{1}$ Moscow State University of Civil Engineering, Russia \\ ${ }^{2}$ Chuvash State University named I.N. Ulyanov, Russia \\ *Email: OrlovVN@mgsu.ru
}

\begin{abstract}
In the article, the authors have developed the method for assessing the innovative development of the Russian economy. For this, an index analysis of the following factors has been carried out: the number of organisations and workers performing research and development; financing innovative activities; advanced manufacturing (nano)technologies in the process brought to the consumer; application of innovative technologies and objects of intellectual property. The integral indicators characterising their changes have been calculated, and the levels of innovative development of the Russian economy have been determined. Then, using the tools of mathematical modelling, a multi-factor mathematical model has been built and tested in real-time that enabled to obtain a high-quality predicted result. Based on the obtained forecasts, it is possible to state the need to adjust specific indicators that actively affect innovative development, which is a mathematical justification for making managerial decisions when developing strategies and programs related to the technological and digital modernisation of the Russian economy.
\end{abstract}

Keywords: Innovative development, Evaluation methodology, Integral indicator, Mathematical modelling.

\section{INTRODUCTION}

The relevance of the research topic is because there is a lack of scientific knowledge in the development of methods for assessing the innovative development of the economy. Since the first publication in 1911, related to the theory of innovation (Schumpeter J.), the terminology is being enriched; there are many similar categories (innovation: economy, process, activity, activity, etc.) and a significant number of regulatory documents describing the innovation [1-5]. All this complicates the assessment of the innovative development of the economy.

Given the shortcomings of publications on this issue, for example, in the works of Asadova S.S. [6], Belski V., Trigubovich L. [7], Luchko M., Szmitka S., Dmuchowski R. [8], the approach to accounting indicators with different units of measurement is not considered. In the works of Delgado M., Porter M., Stern S. [9], Hilty L., Aebischer B. [10], Lee S.J., Lee E.H., Oh D.S. [11] there are no mathematical models for the study of economic processes. Along with that, in the articles of
Njos R., Jakobsen S.E. [12], Yoon D. [13], while the statistical information is enclosed, there is no mathematical apparatus given for research and the possibility of obtaining forecasts. Whereas the capabilities of the current state of mathematics and computer technology enable to obtain high-quality, reliable forecasts based on mathematical models, as evidenced by publications in the field of economics [1415], medicine [16-17], and technology [18-20].

The authors proposed a variant of a mathematical model for research and justification of the measures to improve the quality of indicators of innovation development of the economy. Thus, the purpose of the article is to develop a methodology for assessing the innovative development of the Russian economy using building mathematical models to obtain a high-quality predictable result.

\section{RESEARCH METHODOLOGY}

At the initial stage, a sample of the most important criteria for assessing the innovative development of the 
economy, which are the objects of this study, is formed [21] table 1.

In an enlarged form, it includes a variety of indicators, but for simplification and efficiency of calculations, based on PEST-analysis, twelve factors with a significant impact on the innovative development of the economy have been identified (table 1). The selected factors are provided with accessible information from the website of the Federal state statistics service and are to be added to the index value (in $\%$ of the previous year) in tables $2-5$ to allow their consideration in calculating the integral indicator.

\section{THE RESULTS OF THE STUDY}

The information presented in table 1 is heterogeneous in terms of units of measurement and requires preliminary processing to be included in the study. The paper proposes the use of the technology of the index analysis method [14-15], which allows authors to aggregate a wide range of quantitative indicators of

Table 1. Current indicators characterising the innovative development of the Russian economy in 20102019.

\begin{tabular}{|c|c|c|c|c|c|c|c|c|c|c|}
\hline Indicators & 2010 & 2011 & 2012 & 2013 & 2014 & 2015 & 2016 & 2017 & 2018 & 2019 \\
\hline \multicolumn{11}{|c|}{$\begin{array}{c}\text { OESRD - indicators characterising the number of organisations and employees } \\
\text { performing scientific research and development }\end{array}$} \\
\hline $\begin{array}{l}\text { The number } \\
\text { organisations performed } \\
\text { research and development, } \\
\text { units }\end{array}$ & 3492 & 3682 & 3566 & 3605 & 3604 & 4175 & 4032 & 3944 & 3950 & 4051 \\
\hline $\begin{array}{l}\text { The number of personnel } \\
\text { engaged in scientific } \\
\text { research and development, } \\
\text { thousand people }\end{array}$ & 736.5 & 735.3 & 726.3 & 727.0 & 732.3 & 738.9 & 722.3 & 707.9 & 682.6 & 682.5 \\
\hline \multicolumn{11}{|c|}{ FIA - indicators characterising the financing of innovation activity } \\
\hline $\begin{array}{l}\text { Costs of innovation activity, } \\
\text { billion rubles }\end{array}$ & 400.8 & 733.8 & 904.6 & $\begin{array}{l}1112 . \\
4\end{array}$ & $\begin{array}{l}1211 . \\
9\end{array}$ & $\begin{array}{l}1200 . \\
4\end{array}$ & $\begin{array}{l}1284 . \\
6\end{array}$ & $\begin{array}{l}1405 . \\
0\end{array}$ & $\begin{array}{l}1472 . \\
8\end{array}$ & $\begin{array}{l}1954 . \\
1\end{array}$ \\
\hline $\begin{array}{l}\text { Funding of science from } \\
\text { the Federal budget, billion } \\
\text { rubles }\end{array}$ & 237.6 & 313.9 & 355.9 & 425.3 & 437.3 & 439.4 & 402.7 & 377.9 & 420.5 & 489.2 \\
\hline $\begin{array}{l}\text { Internal research and } \\
\text { development costs, billion } \\
\text { rubles }\end{array}$ & 523.4 & 610.4 & 699.9 & 749.8 & 847.5 & 914.7 & 943.8 & $\begin{array}{l}1019 . \\
2\end{array}$ & $\begin{array}{l}1028 . \\
2\end{array}$ & $\begin{array}{l}1134 . \\
8\end{array}$ \\
\hline \multicolumn{11}{|c|}{$\begin{array}{c}\text { MTPBC -indicators characterising advanced manufacturing (nano)technologies, } \\
\text { being delivered to the consumer }\end{array}$} \\
\hline $\begin{array}{lr}\text { Developed } & \text { advanced } \\
\text { production } & \text { technologies, } \\
\text { units } & \end{array}$ & 864 & 1138 & 1323 & 1429 & 1409 & 1398 & 1534 & 1402 & 1565 & 1620 \\
\hline $\begin{array}{l}\text { The number of developed } \\
\text { nanotechnologies, units }\end{array}$ & 222 & 258 & 327 & 411 & 443 & 505 & 494 & 446 & 402 & 555 \\
\hline $\begin{array}{l}\text { Patent applications filed, } \\
\text { units }\end{array}$ & $\begin{array}{l}5875 \\
9\end{array}$ & $\begin{array}{l}5885 \\
2\end{array}$ & $\begin{array}{l}6292 \\
0\end{array}$ & $\begin{array}{l}6426 \\
6\end{array}$ & $\begin{array}{l}5944 \\
4\end{array}$ & $\begin{array}{l}6235 \\
2\end{array}$ & $\begin{array}{l}5816 \\
3\end{array}$ & $\begin{array}{l}5358 \\
4\end{array}$ & $\begin{array}{l}5361 \\
2\end{array}$ & $\begin{array}{l}5256 \\
7\end{array}$ \\
\hline \multicolumn{11}{|c|}{$\begin{array}{c}\text { ITOIP -indicators characterising the innovative technologies and } \\
\text { intellectual property objects used }\end{array}$} \\
\hline $\begin{array}{l}\text { Domestically-made goods } \\
\text { shipped, including } \\
\text { innovative goods, works } \\
\text { and services, billion rubles }\end{array}$ & $\begin{array}{l}1243 . \\
7\end{array}$ & $\begin{array}{l}2106 . \\
7\end{array}$ & $\begin{array}{l}2872 . \\
9\end{array}$ & $\begin{array}{l}3507 . \\
9\end{array}$ & $\begin{array}{l}3579 . \\
9\end{array}$ & $\begin{array}{l}3843 . \\
4\end{array}$ & $\begin{array}{l}4364 . \\
3\end{array}$ & $\begin{array}{l}4167 . \\
0\end{array}$ & $\begin{array}{l}4516 . \\
3\end{array}$ & $\begin{array}{l}4863 . \\
4\end{array}$ \\
\hline $\begin{array}{l}\text { Information about the use } \\
\text { of intellectual property } \\
\text { objects, thousand units }\end{array}$ & 19.6 & 22.3 & 23.6 & 24.9 & 26.7 & 29.1 & 32.8 & 33.0 & $3 ., 8$ & 47.2 \\
\hline $\begin{array}{l}\text { Used advanced production } \\
\text { technologies, thousand } \\
\text { units }\end{array}$ & 203.3 & 191.7 & 191.4 & 193.8 & 204.5 & 218.0 & 232.4 & 240.1 & 254.9 & 262.6 \\
\hline $\begin{array}{l}\text { Number of active patents, } \\
\text { thousand units }\end{array}$ & 304.3 & 281.3 & 302.8 & 320.4 & 342.8 & 354.2 & 361.5 & 375.0 & 393.6 & $39 ., 3$ \\
\hline
\end{tabular}


innovative economic development, which have different units of measurement and are not comparable with each other without standardisation of values. Based on certain factors taken from the table 1 , table 2 is compiled, reflecting the index values of indicators that characterise the number of organisations and employees performing research and development in the Russian Federation in 2010-2019.

Based on the following factors in table 2, an integral indicator is calculated using the formula (1), which characterises the number of organisations and employees performing scientific research and development $\left(I I_{O E S R D}\right)$ (in points):

$I_{O E S R D}=\sqrt[2]{I_{O E S R D}^{* I_{N P S R D}}}$

where $I_{O E S R D}$ - index changes in the number of organisations engaged in scientific research and development, \%;

$I_{N P S R D}$ - index of changes in the number of personnel engaged in scientific research and development, $\%$.

Then, based on the data taken from table 1, table 3 is compiled, reflecting changes in indicators that characterise the financing of innovation activities in the Russian Federation in 2010-2019.

The figures from table 3 are used to calculate the integral indicator that characterises the financing of innovation activities $\left(I I_{F I A}\right)$, according to the formula (2) (in points):

$I I_{F I A}=\sqrt[3]{I_{C I A^{*} I_{S F F B} I_{I E S R D}}}$

where $I_{C I A}$ - index of changes costs in innovation activity, \%;

$I_{S F F B}$ - index of changes in science funding from the Federal budget, \%;
$I_{I E S R D}$ - index of changes in internal expenditures on science research and development, $\%$.

Then, consider the following group of factors taken from table 1 , table 4 is formed, reflecting the index values of indicators that characterise advanced manufacturing (nano)technologies that are to be delivered to the consumer of the Russian Federation in 2010-2019.

The values of table 4 are necessary for calculating an integral indicator that characterises advanced manufacturing (nano)technologies delivered to the consumer $\left(I I_{A T P B C}\right)$ using the formula (3) (in points):

$I I_{A T P B C}=\sqrt[3]{I_{D A T} * I_{N D N^{*} I_{F P A}}}$

where $I_{D A T}$ - index of changes in developed advanced production technologies, $\%$;

$I_{N D N}$ - index of changes in the number of developed nanotechnologies, \%; $\%$.

$I_{F P A}$ - index of changes in filed patent applications,

Finally, on the remaining group of factors in table 1, table 4 is formed, reflecting the index values of indicators that characterise advanced manufacturing (nano)technologies delivered to the consumer in the future of the Russian Federation in 2010-2019.

Based on the data of table 5, an integral indicator describing the use of innovative technologies and intellectual property objects $\left(I_{\text {UITOIP }}\right)$ is calculated under the formula (4) (in points):

$$
I_{U I T O I P}=\sqrt[4]{I_{S G O P} * I_{U I P O^{*} I_{U A T} * I_{N A P}}}
$$

where $I_{S G O P}$ - index of changes in shipped goods of domestic production, including innovative goods, works, services, \%;

$I_{U I P O}$ - index of changes in the information on the use of intellectual property objects, \%;

Table 2. Dynamics of changes in indicators describing the number of organisations and employees performing research and development in the Russian Federation in 2010-2019, in \% compared to the previous year

\begin{tabular}{|l|l|l|l|l|l|l|l|l|l|l|}
\hline Indicators & 2010 & 2011 & 2012 & 2013 & 2014 & 2015 & 2016 & 2017 & 2018 & 2019 \\
\hline $\begin{array}{l}\text { Index of changes in the } \\
\text { number of organisations } \\
\text { that performed research } \\
\text { and development }\end{array}$ & 97.4 & 105.4 & 96.8 & 101.1 & 99.9 & 115.8 & 96.6 & 97.8 & 100.2 & 102.6 \\
\hline $\begin{array}{l}\text { Index of changes in the } \\
\text { number of employees } \\
\text { engaged in scientific } \\
\text { research and } \\
\text { development }\end{array}$ & 100.1 & 99.8 & 98.8 & 100.1 & 100.7 & 100.9 & 97.8 & 98.0 & 96.4 & 99.9 \\
\hline $\begin{array}{l}\text { An integral indicator that } \\
\text { describes the number of } \\
\text { organisations and } \\
\text { employees performing } \\
\text { research and } \\
\text { development, points }\end{array}$ & 98.7 & 102.6 & 97.8 & 100.6 & 100.3 & 108.1 & 97.2 & 97.9 & 98.3 & 101.2 \\
\hline
\end{tabular}


Table 3. Dynamics of changes in indicators characterising the financing of innovation activities in the Russian Federation in 2010-2019, \%, in comparison with the previous year

\begin{tabular}{|l|l|l|l|l|l|l|l|l|l|l|}
\hline Indicators & 2010 & 2011 & 2012 & 2013 & 2014 & 2015 & 2016 & 2017 & 2018 & 2019 \\
\hline $\begin{array}{l}\text { Index of changes in } \\
\text { innovation activity costs }\end{array}$ & 70.6 & 183.1 & 123.3 & 123.0 & 108.9 & 99.0 & 107.0 & 109.4 & 104.8 & 132.7 \\
\hline $\begin{array}{l}\text { Index of changes in } \\
\text { science funding from the } \\
\text { Federal budget }\end{array}$ & 86.2 & 132.1 & 113.4 & 119.5 & 102.8 & 100.5 & 91.7 & 93.8 & 111.3 & 85.6 \\
\hline $\begin{array}{l}\text { Index of changes in } \\
\text { domestic research and } \\
\text { development } \\
\text { expenditures }\end{array}$ & 92.3 & 116.7 & 114.7 & 107.1 & 113.0 & 107.9 & 103.2 & 108.0 & 100.9 & 110.4 \\
\hline $\begin{array}{l}\text { Integral } \\
\text { characterising financing } \\
\text { of innovation activity, } \\
\text { points }\end{array}$ & 82.5 & 141.3 & 117.1 & 116.3 & 108.2 & 102.4 & 100.4 & 103.5 & 105.6 & 107.8 \\
\hline
\end{tabular}

$I_{U A T}$ - index of changes and used advanced production technologies, $\%$.

$I_{N A P}$ - index of changes in the number of patents in force, $\%$.

Thus, we come to the formula (5) for calculating the integral indicator of innovative development of the economy $\left(I I_{I . D . E .}\right)$, (in points):

$I I_{\text {I.D.E. }}=\frac{I I_{O E S R D}+I I_{F I A}+I I_{A T P B C}+I_{U I T O I P}}{4}$

where $I I_{O E S R D}$ an integral indicator that characterises the number of organisations and employees performing scientific research and development, points;

$I I_{F I A}$ - an integral indicator that characterises the financing of innovation activities, points;

$I I_{A T P B C}$ - an integral indicator characterising advanced manufacturing (nano)technologies that are in the process of being brought to the consumer, points;

$I I_{\text {UITOIP }}$ - an integral indicator describing the use of innovative technologies and intellectual property objects, points.

Table 4. Dynamics of changes in indicators that characterise advanced manufacturing (nano)technologies delivered to the consumer in Russian Federation in 2010-2019, in \% of the previous year

\begin{tabular}{|l|l|l|l|l|l|l|l|l|l|l|}
\hline \multicolumn{1}{|c|}{ Indicators } & $\begin{array}{c}\text { for } \\
2010\end{array}$ & 2011 & 2012 & 2013 & 2014 & 2015 & 2016 & 2017 & 2018 & 2019 \\
\hline $\begin{array}{l}\text { Index of changes in raw } \\
\text { advanced production } \\
\text { technologies }\end{array}$ & 86.3 & 131.7 & 116.3 & 108.0 & 98.6 & 99.2 & 109.8 & 91.4 & 111.6 & 103.5 \\
\hline $\begin{array}{l}\text { Index of changes in the } \\
\text { number of developed } \\
\text { nanotechnologies }\end{array}$ & 92.5 & 116.2 & 126.8 & 125.7 & 107.8 & 114.0 & 97.8 & 90.3 & 90.1 & 138.1 \\
\hline $\begin{array}{l}\text { Index of changes in filed } \\
\text { patent applications }\end{array}$ & 99.9 & 100.2 & 106.9 & 102.1 & 92.5 & 104.9 & 93.3 & 92.1 & 100.1 & 98.1 \\
\hline $\begin{array}{l}\text { An integral indicator } \\
\text { that characterises } \\
\text { advanced manufacturing } \\
\text { (nano)technologies } \\
\text { delivered to the consumer, } \\
\text { points }\end{array}$ & 92.7 & 115.3 & 116.4 & 111.5 & 99.4 & 105.9 & 100.1 & 91.3 & 100.2 & 111.9 \\
\hline
\end{tabular}

The values of the integrated indicator of innovative development of the economy $\left(I I_{I . D . E .}\right)$ are presented in table 6 .

Based on our calculations, we determine the following levels of innovative development of the

Russian economy:

$I I_{I . D . E .}>110,0$ points - high level;

$100,0<I I_{I . D . E .}<110,0$ points - medium level;

$I I_{I . D . E .}<100,0$ points - low level.

The results of calculations indicate that in the analysed period, the level of innovative development of the Russian economy was mainly average, and only in 2010 and 2017 it fell below 100.0 points and amounted to 92.7 and 98.4 points, respectively. In 2011, this level rose to a record 118.3 points (for 2010-2019) and in 2012 - to 110.8 points.

Based on the correlation analysis and elimination of correlation of factors presented in Table 6 , the structure of the multi-factor model was optimised, gradually eliminating the $4^{\text {th }}$ and then the $3^{\text {rd }}$ factors from 
Table 5. Dynamics of changes in indicators characterising the use of innovative technologies and intellectual property objects in Russian Federation in 2010-2019, in \% compared to the previous year

\begin{tabular}{|l|l|l|l|l|l|l|l|l|l|l|}
\hline \multicolumn{1}{|c|}{ Indicators } & 2010 & 2011 & 2012 & 2013 & 2014 & 2015 & 2016 & 2017 & 2018 & 2019 \\
\hline $\begin{array}{l}\text { Index of changes in shipped } \\
\text { domestically-made } \\
\text { including innovative goods, } \\
\text { works, and services }\end{array}$ & 74.2 & 169.3 & 136.4 & 122.1 & 102.1 & 107.4 & 113.6 & 95.5 & 108.4 & 107.7 \\
\hline $\begin{array}{l}\text { Index of changes in information } \\
\text { about the use of intellectual } \\
\text { property objects }\end{array}$ & 93.6 & 113.6 & 106.1 & 105.6 & 107.2 & 109.0 & 112.4 & 100.7 & 120.7 & 118.6 \\
\hline $\begin{array}{l}\text { Index of changes and applied } \\
\text { advanced } \\
\text { technologies manufacturing }\end{array}$ & 103.0 & 94.3 & 99.9 & 101.3 & 105.6 & 106.6 & 106.6 & 103.3 & 106.2 & 103.0 \\
\hline $\begin{array}{l}\text { Index of changes in the number } \\
\text { of active patents }\end{array}$ & 103.9 & 92.4 & 107.6 & 105.8 & 107.0 & 103.3 & 102.1 & 103.7 & 104.9 & 101.4 \\
\hline $\begin{array}{l}\text { Integral indicator describing the } \\
\text { use of innovative technologies } \\
\text { and intellectual property objects, } \\
\text { points }\end{array}$ & 92.9 & 113.8 & 111.7 & 108.4 & 105.5 & 106.6 & 108.6 & 100.7 & 109.9 & 107.5 \\
\hline
\end{tabular}

consideration. As a result, we get the structure of a multivariate model of the form:

$Y=a_{0}+a_{1} x_{1}+a_{2} x_{2}$

where

$a_{0}=19.95928615, \mathrm{a}_{1}=0.372341289, \mathrm{a}_{2}=0.439462288$

The resulting multivariate regression equation has a multiple determination coefficient $R_{2}=0.9239$. The significance of the regression equation was confirmed using the Fisher test at the significance level $\mathrm{a}=0.05$ and $F_{\mathrm{cr}}=4.45 ; F_{\mathrm{obz}}=42.5098216$. The competing hypothesis

$H_{1}: R^{1} 0$, which confirms the significance of the constructed multi-factor model (6). A geometric interpretation of the model is shown in figure 1 .

The constructed multi-factor regression model (6) was tested on data from 2010 to 2018. Coefficients have values: $\quad a_{0}=21,99993465 ; \quad a_{1}=0,347532675$; $\mathrm{a}_{2}=0,441420119$. The coefficient of multiple

Table 6. Integrated indicator of innovative economic development of the Russian Federation in 20102019 , in points

\begin{tabular}{|c|c|c|c|c|c|c|c|c|c|c|}
\hline Indicators & 2010 & 2011 & 2012 & 2013 & 2014 & 2015 & 2016 & 2017 & 2018 & 2019 \\
\hline $\begin{array}{c}\text { Integrated indicator of } \\
\text { innovative economic } \\
\text { development, points } \\
\left(I I_{\text {I.D.E. }}\right)\end{array}$ & 91.7 & 118.3 & 110.8 & 109.2 & 103.4 & 105.8 & 101.6 & 98.4 & 103.5 & 107.1 \\
\hline $\begin{array}{l}\text { An integral indicator that } \\
\text { describes the number of } \\
\text { organisations and employees } \\
\text { performing research and } \\
\text { development, points } \\
\left(I_{\text {OESRD }}\right)\end{array}$ & 98.7 & 102.6 & 97.8 & 100.6 & 100.3 & 108.1 & 97.2 & 97.9 & 98.3 & 101.2 \\
\hline $\begin{array}{l}\text { Integral indicator that } \\
\text { characterises financing of } \\
\text { innovation } \\
\text { points }\left(I I_{F I A}\right)\end{array}$ & 82.5 & 141.3 & 117.1 & 116.3 & 108.2 & 102.4 & 100.4 & 103.5 & 105.6 & 107.8 \\
\hline $\begin{array}{l}\text { An integral indicator } \\
\text { that characterises advanced } \\
\text { manufacturing } \\
\text { (nano)technologies that are in } \\
\text { the process of being brought } \\
\text { to the consumer, points } \\
\left(I I_{A T P B C}\right)\end{array}$ & 92.7 & 115.3 & 116.4 & 111.5 & 99.4 & 105.9 & 100.1 & 91.3 & 100.2 & 111.9 \\
\hline $\begin{array}{l}\text { Integral indicator that } \\
\text { characterises the use of } \\
\text { innovative technologies and } \\
\text { intellectual property objects, } \\
\text { points }\left(I I_{\text {UITOIP }}\right)\end{array}$ & 92.9 & 113.8 & 111.7 & 108.4 & 105.5 & 106.6 & 108.6 & 100.7 & 109.9 & 107.5 \\
\hline
\end{tabular}


determination $R_{2}=0,933628391$. The significance of the model is confirmed by the Fisher criterion at the significance level $a=0,05$ and $F c r=4,54$; Fobz $=42,20004923$. The competing hypothesis $H_{1}: R^{1} 0$. The significance of the constructed multifactor model is confirmed.

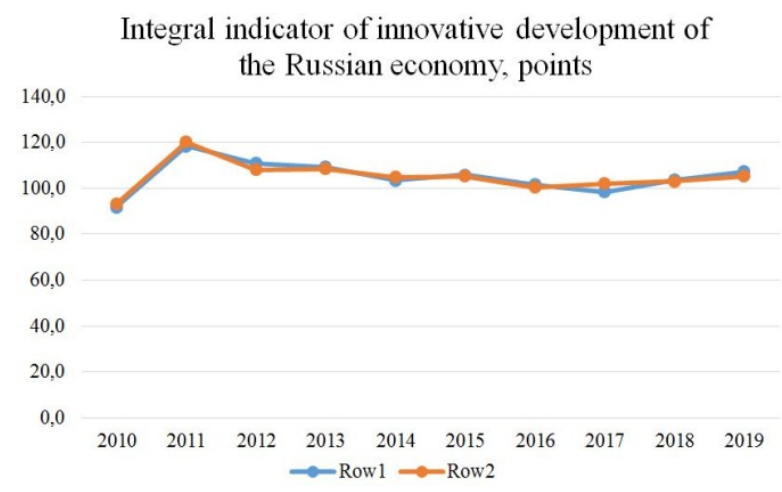

Figure 1 Geometric interpretation of a multi-factor model, where row 1 is the source information, row 2 is the multi-factor model.

The confidence interval of the predicted value of the index of innovative development of the economy of $I I_{\text {I.D.E. }}=\mathrm{Y} 2019$

$$
95.9549 \leq \mathrm{Y} 2019 \leq 109.5978 .
$$

Considering that in 2019 the actual value of $I I_{I . D . E}$.

is within the obtained confidence interval and is 107.8 points, which indicates the accuracy of the predicted values for the innovative development rates describing the state of the Russian economy.

\section{DISCUSSION OF RESULTS}

Similarly, the confidence interval of the predicted value of $I I_{\text {I.D.E. }}$ for 2020 was obtained:

$$
97,0257 \leq Y_{2020} \leq 113,0028 \text {. }
$$

Its range is higher than the indicators of 2019, which proves the effectiveness of measures implemented within the framework of the "Strategy for Scientific and Technological Development of the Russian Federation", "Strategy for Innovative Development of the Russian Federation for the Period until 2020" and the state program "Economic Development and Innovative Economy" related to technological and digital modernisation.

The analysis of $I I_{O E S R D}$ revealed that for 2010-2019. The total change in the index of the number of organisations performing research and development was $9.2 \%$, and the index of changes in the number of personnel engaged in research and development $-0.05 \%$. Accordingly, the first parameter has a more significant impact on the integral indicator, which characterises the number of organisations and employees performing research and development.

Analysis of $I I_{F I A}$ shows that over the analysed period, the total change in the indices had the following values: $188.9 \%$ of innovation expenditures, $108.5 \%$ of science funding from the Federal budget, and $122.6 \%$ of internal research and development expenditures. Consequently, the change in the innovation expenditure index had the most significant impact on the integral indicator that characterises innovation financing.

\section{CONCLUSIONS}

Thus, the developed algorithm is a unique tool for assessing the innovative development of the Russian economy. It is a universal and accurate means of forecasting for the next period and has excellent potential for further research since it can be used to assess the impact of not only innovative factors but also economic, social, political, legal, environmental and other indicators on the development of the country, Federal districts and regions. The methodology could serve as one of the bases for legislative and executive authorities in the development of socio-economic projects and programs.

\section{REFERENCES}

[1] About the strategy of scientific and technological development of the Russian Federation: Decree of the President of the Russian Federation from 01.12.2016 №642, Collection of legislation of RF [Collection of legislation of RF] 4949 (2016) 6887.

[2] On approval of the state program of the Russian Federation "Economic development and innovative economy": the resolution of the Government of the Russian Federation of 15.04.2014 №316, Collection of legislation of RF 18-18 (part II) (2014) 2162.

[3] On approval of the strategy of innovative development of the Russian Federation for the period up to 2020: decree of the Government of the Russian Federation dated 08.12.2011 №2227-R, Collection of legislation of RF 1 (2011) 216.

[4] Forecast of long-term socio-economic development of the Russian Federation for the period up to 2030 (developed by the Ministry of economic development of the Russian Federation), consultant plus [Electronic resource]. Retrieved from: http://www.consultant.ru/document/cons doc LA $\underline{\mathrm{W} \quad 144190}$

[5] National centre for monitoring innovation infrastructure of scientific and technical activities and regional innovation systems [Electronic resource]. Retrieved from: http://www.miiris.ru 
[6] S.S. Asadova, Methodology for assessing the level of digitalisation of the economy, Economic News of the National Academy of Sciences of Azerbaijan 3 (2020) 39-48.

[7] V. Belski, L. Trigubovich, Motivational basis of an innovative activity as a source of intensification of innovative economic development, Proceedings of the National Academy of Sciences of Belarus, Humanitarian Series 64 (2019) 502-509. DOI: https://doi.org/10.29235/2524-2369-2019-64-4502-509

[8] M. Luchko, S. Szmitka, R. Dmuchowski, Start-up as an innovative economic entity, Galic'kij ekonomičnij visnik 602019 16-26. DOI: https://doi.org/10.33108/galicianvisnyk tntu2019.0 $\underline{5.016}$

[9] M. Delgado, M. Porter, S. Stern, Defining Clusters of Related Industries, Journal of Economic Geography Vol. 16:1 (2016) 1-38.

[10] L. Hilty, B. Aebischer, ICT innovations for sustainability, London: Springer, 2015, 470 p.

[11] S.J. Lee, E.H. Lee, D.S. Oh, Establishing the innovation platform for sustainable regional development: Tech-valley project in Sejong city, Korea, World Technopolis Review 6(1) (2017) 7586.

[12] R. Njos, S.E. Jakobsen, Cluster policy and regional development: Scale, scope and renewal, Regional Studies, Regional Science 3(1) (2016) 146-169.

[13] D. Yoon, The regional-innovation cluster policy for R\&D efficiency and the creative economy: With a focus on daedeok innopolis, Journal of Science and Technology Policy Management 8(2) (2017) 206226.

[14] V.N. Orlov, T.V. Ivanova, V.A. Arkhipova, I.P. Ivanitskaya, Assessment of the influence of social factors on reproduction of personnel potential in agriculture of Russia, PbWOSCE-2018: Business technologies for sustainable urban development. E3S Web Conf., 110, 2019, DOI: ttps://doi.org/10.1051/e3sconf/201911002143

[15] V.N. Orlov, T.V. Ivanova, S.A. Brechagova, N.N. Rumbayeva, Mathematical modelling of economic factors impact: reproduction of personnel potential in the agriculture sector of Russia, IOP Conf. Series: Earth and Environmental Science 433, 2020, 012012 IOP Publishing. DOI: ttps://doi.org/10.1088/1755-1315/433/1/012012

[16] V.N. Orlov, T.Yu. Vinokur, A.G. Ivanov, V.L. Suslikov. Development of a mathematical model for assessing the dynamics of morbidity and mortality from cardiovascular diseases in the territory of the Chuvash Republic, Disease prevention and health promotion 5 (2007) 44-47.

[17] V.N. Orlov, A.V. Samoilova, A.G. Gunin, S.G. Minaev, Mathematical modelling in the study of the effectiveness of in vitro fertilisation, Kazan Medical Journal 6 (2009) 889-892.

[18] V.N. Orlov, O.A. Kovalchuk, E.P. Detina, Mathematical modelling of emergencies at objects of production and gas transportation 04012, VI International Scientific Conference «Integration, Partnership and Innovation in Construction Science and Education» (IPICSE-2018), MATEC Web of Conferences, 251, 2018, DOI: https://doi.org/10.1051/matecconf/201825104012

[19] V.N. Orlov, E.P. Detina, Probabilistic approach to the investigation of the causes of emergencies at the gas pipeline facilities 04041, VI International Scientific Conference «Integration, Partnership and Innovation in Construction Science and Education» (IPICSE-2018), MATEC Web of Conferences, 251, 2018 , DOI: https://doi.org/10.1051/matecconf/201825104041

[20] V.N. Orlov, O.A. Kovalchuk, Mathematical modelling of complex structures and nonlinear differential equations with movable points, IOP Conf. Series: Materials Science and Engineering, 456, 2018, 012122 IOP Publishing. DOI: https://doi.org/10.1088/1757-899X/456/1/012122

[21] Materials of the Federal State Statistics Service [Electronic resource]. Retrieved from: https://rosstat.gov.ru/ 